\title{
SOCIAL AND ECONOMIC DETERMINANTS OF THE DEVELOPMENT OF GROUPS OF AGRICULTURAL PRODUCERS IN POLAND
}

Joanna ZIELIŃSKA-SZCZEPKOWSKA, Department of Economic and Regional Policy, University of Warmia and Mazury, ul. Oczapowskiego 4 10-719 Olsztyn, Poland, joanna.zielinska@uwm.edu.pl (corresponding author)

Izabela ZABIELSKA, Department of Economic and Regional Policy, University of Warmia and Mazury, ul. Oczapowskiego 4, 10-719 Olsztyn, Poland, izus@uwm.edu.pl

Roman KISIEL, Department of Economic and Regional Policy, University of Warmia and Mazury, ul. Oczapowskiego 4, 10-719 Olsztyn, Poland

The aim of the article was to characterize the aspects of social and economic conditions and circumstances for the establishment and operation of groups of agricultural producers in Poland. The discussion is theoretical. In the article the monographic method was used. The following issues were subsequently examined: the nature and status of groups of producers in Poland, the social capital of farmers, advantages and obstacles in the cooperation of agricultural farmers and financial aid opportunities under the Rural Development Programmes for 2007-2013 and 2014-2020. As the example, the model of agricultural producer groups functioning in Poland was described.

The results of the consideration has broad spectrum. It follows from the analysis conducted that the reasons for creating groups of producers are economic benefits related to production on a higher scale and to achievement of synergies through acting together. They also include EU financial aid opportunities. The benefits are also of a social character and are related, among others, to farmers learning how to act together as well as to increased trust in cooperation.

In spite of numerous benefits that may arise from acting together, there are also certain obstacles related to the level of knowledge or educational background of farmers, typical responses to change or lack of trust between organisation members. This is often an effect of negative past experiences connected with overall socialisation that affects postcommunist nations.

Keywords: agricultural producer groups in Poland, social capital, cooperation, economic benefits and costs

\section{INTRODUCTION}

The idea of cooperation currently underlies the discussion about the development of market entities (organisations) and social groups. It is more often the case that growing competition requires growing cooperation (Adamik, 2007). The last few decades have brought about significant changes in the business environment, mainly due to progressive globalisation which manifests itself, among others, in international concentration of production. Changes in the environment increase the costs of building a market advantage on one's own, hence companies (agricultural ones as well) decide to cooperate with competitors. In the global economy, a crisis in development based on independent activities is particularly visible (Glabiszewski and Sudolska, 2009).

There are many definitions of cooperation in the literature on the subject. Cameron et al. (2004) believes that cooperation is a social phenomenon, an organisational concept which dates back to prehistoric times (when man began to walk on Earth) and is highly desirable today. It applies, among others, to the cooperation of farmers who traditionally provided agricultural, production and construction services to their neighbours and who nowadays combine their efforts and form groups of producers to jointly undertake various ventures.

Cooperating agricultural producers gain various economic, organisational and social benefits - as described by numerous authors (see Chlebicka et al., 2008; Jenkins, 2003; Lemanowicz, 2004; Prus et al., 2009). According to Corning (1998), if one considers those benefits to be interdependent, then synergy of cooperation occurs. The fact that producers engage in production activities is a result of increased performance efficiency, but it also entails the integration of creative human functions.

The formation of groups of producers is a manifold process; it is not limited only to strengthening the market position of multiple affiliated farms, but it also improves the social lives of families owning those farms, resulting in both

Copyright (C) 2017 The Authors. Published by Aleksandras Stulginskis University. This is an open-access article distributed under the terms of the Creative Commons Attribution License (CC-BY 4.0), which permits unrestricted use, distribution, and reproduction in any medium, provided the original author and source are credited. 
formal and informal relations that create social capital at a local level and a regional level (Szeląg-Sikora and OleksyGębczyk, 2013).

In the light of the foregoing, a research problem tackled in this article is an attempt to answer the following questions: which elements of social capital are determinants of long-term relations between farmers and which socioeconomic advantages and costs arise from cooperation of agricultural producers operating in Poland in groups.

\section{MATERIALS AND RESEARCH METHODS}

The purpose of the research was to present social and economic aspects that lead to forming groups of agricultural producers in Poland. The article presents conditions and circumstances related to farmers' social capital as well as socioeconomic advantages and costs of cooperation in groups of agricultural producers, including experiences and financial aid opportunities under the Rural Development Programmes for 2007-2013 and 2014-2020.

This paper is an overview based on the literature on the subject, on national and EU legal regulations on support for groups of agricultural producers and on secondary sources of the Ministry of Agriculture and Rural Development as well as of the Agency for Restructuring and Modernisation of Agriculture. The results of the analysis are described and presented in tables.

\section{GROUPS OF AGRICULTURAL PRODUCERS IN POLAND}

In Poland, the operation of groups of agricultural producers as well as the rules and requirements for granting financial aid from public funds in relation to their formation are governed by the Act of 15 September on Groups and Associations of Agricultural Producers (Dz.U. No. 88, item 983). This Act governs financial state aid provided in the first five years of activity of a registered group, credits on preferential terms for group's core objectives and real estate tax exemptions. Since the Act failed to activate farmers and engage them in forming groups and organisations of producers, it was later amended, with three of those amendments being particularly important. The first amendment of 18 June 2004 (Dz.U. of 2004 No. 62, item 1694) allowed legal persons to join groups and provided for larger financial aid for groups. Of great importance was also allowing cooperatives and companies to join such groups of producers. The amendment resulted in new groups of around 30 cooperatives. The second amendment of 15 December 2006 (Dz.U. of 2006 No. 251, item 1847) provided for income tax and real estate tax exemption for groups of producers. Those amendments were not used to the fullest because groups possessed real estate very rarely and earned a profit only occasionally. Producers in groups were more interested in purchasing new production equipment and attracting new customers rather than in generating income. The third amendment of 9 April 2008 (Dz.U. of 2008 No. 72, item 424) reduced the minimum annual volume of commercial production in individual voivodeships. This amendment was addressed to producers of low potential, but in reality it did not accelerate the formation of groups. It mainly helped large commercial farms form their groups; owners established 5-person companies, usually family ones. Similarly, reducing the minimum annual commercial production of farms and crop areas did not make related producers form groups (Krzyżanowska 2013).

On 11 September 2015, the Act on Amending the Act on Groups and Associations of Agricultural Producers and on Amending Other Laws and the Act on Supporting Rural Areas from the Funds of the European Agricultural Fund for Rural Development under the Rural Development Programme for 2014-2020 (Dz.U. of 2015, item 1888) were adopted. The foregoing Act introduced many changes relating, among others, to the registration process, monitoring and transferring supervision to divisions of the Agricultural Market Agency from provincial marshal's offices.

Pursuant to the Act on groups and associations of agricultural producers, in Poland, such groups and associations may be joined by individuals, business units without legal personality and legal persons who, as part of their agricultural activity, have an agricultural holding within the meaning of the agricultural tax regulations or a special agricultural production unit.

The foregoing may associate with each other and form groups of agricultural producers in order to adapt agricultural production to the market conditions; to trade in products, including preparation for sale, sale centralisation, and supply to wholesalers; to set general rules on production information, with particular regard to harvesting and availability of agricultural products; to develop business and marketing skills; to arrange and facilitate innovation processes; and to protect the environment. There are three forms of business that groups of producers may choose from: a cooperative, a limited liability company (Polish sp. z o.o.) and an association (Zielińska-Szczepkowska, Kisiel 2016).

Polish groups of agricultural producers have been formed and organised for the last 16 years. According to data of the National Rural Network [2014], the initial interest in forming groups of producers was insignificant - from eight groups in 2001 to 50 groups in 2006. Even after Poland's accession to the EU in 2004 and despite funds provided for such groups in 2004-2006, it did not result in increasing the number of registered groups of producers. The reason for such a state of affairs included, among others, farmers' disapproval of the EU and lack of coordinated agricultural support and advisory programmes.

Adopting the Rural Development Programme for 2007-2013 resulted in a steady increase in the number of groups producers in Poland - from 104 groups in 2007 to 389 groups in 2013. At the end of April 2015, voivodeship marshal offices' registers included 1,338 groups of agricultural producers (Tab. 1). It is worth noting that almost $50 \%$ of them operated in 3 voivodeships (Wielkopolskie - 414, Dolnośląskie - 130, and Kujawsko-Pomorskie - 121). The lowest concentration of groups was noted in the Świętokrzyskie voivodeship (15) and the Małopolskie voivodeship (19). 
Table 1. Number of agricultural producers in Poland (as at 30 April 2015)

\begin{tabular}{l|cc}
\multicolumn{1}{c}{ Voivodeship } & \multicolumn{2}{c}{ Groups of agricultural producers } \\
\cline { 2 - 3 } Dolnośląskie & 130 & 9.6 \\
Kujawsk-Pomorskie & 121 & 9.1 \\
Lubelskie & 33 & 2.5 \\
Lubuskie & 70 & 5.3 \\
Lódzkie & 36 & 2.7 \\
Małopolskie & 19 & 1.3 \\
Mazowieckie & 75 & 5.6 \\
Opolskie & 87 \\
Podkarpackie & 43 \\
Podlaskie & 43 \\
Pomorskie & 74 \\
Śląskie & 27 \\
Świętokrzyskie & 15 \\
Warmińsko-Mazurskie & 85 \\
Wielkopolskie & 414 \\
Zachodniopomorskie & 66 \\
\hline Total in Poland & $\mathbf{1 , 3 3 8}$ \\
\hline Source: own research based on data from the Ministry of Agriculture and Rural Development www.minrol.gov.pl [25 June 2015]. & 3.2 \\
\end{tabular}

Those groups are spread unevenly and diversely. They are formed mostly in regions where commercial and specialised agricultural holdings dominate, with those among them that once belonged to the socialised economy sector, examples of which are the Pomorskie voivodeship and the Warmińsko-Mazurskie voivodeship. What is more, it is worth mentioning that it is not the number, but the size and specialisation of an agricultural holding which are of significance for farmers who want to form a group.

Though the data reveal a continuing trend when it comes to the number of groups of producers in Poland, there is much to be done in this field. In 2004, Polish groups of producers comprised only $1 \%$ of all farmers, whereas in Member States it averages 40\% (Czapiewska 2013). In 2014, groups of producers comprised only $0.08 \%$ of all the agricultural holdings in Poland and $0.19 \%$ of all the holdings above 5ha. In total, all of the Polish groups of agricultural producers in 2013 comprised 28,089 members, which gives an average of 20 people per group. Most members were in groups of tobacco producers $(11,122$ people), even though there were only 11 of them in 2013 . This arises from the labour intensity of cultivation and the specific nature of tobacco production. Other sectors with the largest number of members include: pig producers $(5,038)$, milk producers $(4,187)$, producers of cereal grains and oilseeds $(2,729)$, and poultry producers $(1,535)$ (National Rural Network 2014).

Apart from the foregoing, groups of fruit and vegetable producers are also popular in Poland. As suggested by the Agency for Restructuring and Modernisation of Agriculture [2014], in 2004 there were 24 groups of fruit and vegetable producers, in 2006 - 64 and in 2012 - 238. Since 2013, their number has been decreasing - from 216 (2013) to 142 (2014). Groups of fruit and vegetable producers have emerged mainly in regions with many years of production traditions, i.e. the Mazowieckie, Wielkopolskie, and Kujawsko-Pomorskie voivodeships. In 2014, in the said regions there were 57.5\% of recognised groups of fruit and vegetable producers, though most of them (31.4\%) were in the Mazowieckie voivodeship.

\section{IMPORTANCE OF SOCIAL CAPITAL FOR THE ESTABLISHMENT AND OPERATION OF GROUPS OF AGRICULTURAL PRODUCERS}

In addition to institutional factors that are substantially determined by the state policy, of relevance for the establishment and operation of groups of agricultural producers are unquestionably resources available to farmers. It is not about tangible resources, meaning equipment, land or funds, but about less noticeable resources, meaning social capital.

The benefits of groups of producers arise from the creation of a trust-based informal network of relations that bring about external effects for the entire community (Sierocińska, 2011). Those benefits, called social capital, contribute to more effective cooperation in the future. The result of Woolcock's research on social capital (2001) were six determinants of social capital as described in Table 2.

According to Będzik (2008), it is social capital represented in the relations between actors of the local stage that fosters cooperation and building up trust, which in turn can translate into local development. Additionally, as suggested by Wojewódzka (2006), social capital:

- allows for the circulation of so-called tacit knowledge (not codified and not subject to market mechanisms, but immortalised in the memory of the area (Pietrzyk, 2000, p. 28)

- is important in collective learning, and knowledge accumulated in a given environment facilitates out-of-market diffusion of knowledge, skills, and innovation

- increases competitive abilities of the local environment vis-à-vis continuously changing surroundings

- by entailing characteristic network relations between economic operators - allows for economies of scale and the creation of new knowledge, innovation, becoming the primary aspect of regional competitiveness

- allows for reducing transaction costs by "producing" social norms related to the sense of belonging and identity

- $\quad$ ensures easier decision-taking at various levels, makes it easier to predict the reactions of others

- by providing a model of behaviour - allows for the identification and exclusion of people from the society who do not follow the model or try to use the community for their private purposes (Kostro, 2005, p. 19). 
Table 2 Determinants of social capital

\begin{tabular}{|c|c|}
\hline Item & Description \\
\hline $\begin{array}{l}\text { 1. Place in the network of } \\
\text { relations }\end{array}$ & $\begin{array}{l}\text { - The core component of the creation and existence of social capital are more or less dense } \\
\text { networks of interrelations between individuals and groups } \\
\text { - People establish relationships with each other through relations at various levels, though they } \\
\text { have to be voluntary and comparable } \\
\text { - Social capital may not be generated by individual activity for one's own benefit; thus, it is } \\
\text { dependent on the tendency of individuals towards collective action, on the capacity to generate } \\
\text { new relations, contacts and networks. }\end{array}$ \\
\hline 2. Reciprocity of actions & $\begin{array}{l}\text { - Social capital means an action of an individual to the benefit of others, even at the expense of } \\
\text { their own benefit, expecting that such an action will be reciprocated in the future. }\end{array}$ \\
\hline 3. Trust & $\begin{array}{l}\text { - It makes organisation members take a risk, which results from the assumption that others will } \\
\text { behave as expected and will support each other } \\
\text { - Trust builds a sense of security among organisation members and it fosters information } \\
\text { openness. }\end{array}$ \\
\hline 4. Social norms & $\begin{array}{l}\text { - They are a source of internal, informal social control which "removes" the need to introduce } \\
\text { more formal and institutional sanctions to the network } \\
\text { - They are unwritten but universally understood principles that tell which behaviours are } \\
\text { desirable and approved in a particular social context. }\end{array}$ \\
\hline $\begin{array}{l}\text { 5. Creation of } \\
\text { communities }\end{array}$ & $\begin{array}{l}\text { - A mixture of trust, networks, norms and reciprocity forms a strong community where mutually } \\
\text { shared ownership of resources exists } \\
\text { - Every participant of the network has access to resources, but no one has them for their own. }\end{array}$ \\
\hline 6. Pro-activity & $\begin{array}{l}\text { - Development of social capital requires voluntary and active involvement of people in the joint } \\
\text { participation in action in a community } \\
\text { - Pro-active people are organisation members } \\
\text { - Pro-activity means that social capital defines people as creators of efficiency and not as its } \\
\text { victims. }\end{array}$ \\
\hline
\end{tabular}

Source: own analysis based on Woolcock, 2001.

A group of agricultural producers is primarily an association of people who pursue a common economic goal. The people forming a group themselves are supposed to define rules of cooperation within their organisation as well as rules of cooperation of its members within the group. If a group being an association of individuals is ill-organised, one should not expect good economic performance.

Studies of agricultural cooperatives conducted by Fulton (1999) indicate that the basis for cooperation between farmers is trust. It determines the loyalty of members to the group and their involvement in group's tasks. Trust which is usually developed during many years of contacts and is based on a well-known, positive opinion of the market about a given entity; it is the foundation for development of partnerships. Therefore, trust is the basis for reciprocal obligation of partners to maintain the continuity of the relationship. According to the results of empirical research conducted by Morrow et al. (2003) and Chlebicka (2011), there is a correlation between the trust between group members and the performance of a group of producers. The latter author, in her research carried out with the application of the Delphi method among a group of eight experts, individualised four categories of factors that may contribute to success or failure of groups of producers: production factors, marketing factors, organisational factors and social factors. In the last category, Chlebicka included former cooperation of producers, relations between group members, average age of group members, their educational background and their job seniority.

As far as trust between the parties is concerned, it may be considered in two dimensions: an internal dimension being the credibility of the partner and the tradition of cooperation as well as an external dimension being social capital. Matysiak (1999) defined social capital as the ability of interpersonal cooperation in a given group in order to pursue common interests. On the other hand, Murray (2005) noted that an economic analysis of an agricultural cooperative generally omits the influence of social capital on the functioning of this form of production. Meanwhile, failure to consider the social factor when analysing issues related to the establishment and operation of groups of agricultural producers is a big mistake.

In Poland, only after 1989, when a multi-market economy was introduced and cooperative structures collapsed, the process of creating formal frameworks of cooperation between farmers and of re-building trust between them commenced once again. The beginning of changes resulted in a slight increase in mutual trust (in 1992, a percentage of people trusting others in Poland was 10.3\%), reaching the first maximum in 2002 (13.8\%), and then again fluctuated at a lower level (from $10.5 \%$ in 2003 to $15.1 \%$ in 2015). It is noteworthy that the EU average percentage of people trusting others over 1992-2015 was 38.1\% and it was 2-3 times higher than the Polish average percentage (Diagnoza spoleczna..., 2016, p. 361).

Unfortunately, many publications researching rural areas confirm these data. Researchers agree that inhabitants of rural areas in Poland exhibit low trust towards other people, including fellow inhabitants (cf. Halamska 2011; Wieruszewska 2002; Fedyszak-Radziejowska 2006; Chlebicka et al. 2014). They also indicate the problems of moral relativism and selective adherence to social norms, as well as their negative consequences such as excessive politicisation of local authorities or corruption (Kłodziński 2006). They also point to the poor condition of civil society, which, if it exists at all, has a familial or egoistical character. This problem is also described in analyses diagnosing impediments to cooperative behaviours as stemming from the low trust of rural inhabitants towards their social environment, as well as state and local governments (cf. Michalewska-Pawlak 2010). 
The low level of social trust among farmers is precipitated by, among others, several decades of agricultural production being subjected to the state and its politics under the ruling economic and political system in Poland and other countries of the former post-communist system. This experience has severely undermined social ability to undertake initiatives based on loyalty, commitment and trust. An investigation by Chloupkova et al. (2003) into social capital in Poland and Denmark has shown that although a strong cooperative movement was present in both countries before the Second World War, a great disparity has arisen in social capital after the war and persists until modern times. That disparity was mainly due to central planning which dominated Polish agriculture for years, with forced collectivisation and a degenerated form of cooperative activity in the People's Republic of Poland.

These observations do not paint a very optimistic picture of social capital in Polish rural areas. The negative experiences of farmers in communist times offer a natural explanation for the relatively slow development of collaboration among agricultural producer groups in Poland. At the same time, an increasing number of researchers suggest that this heritage of communism, although marred by the scars of homo sovieticus, may be viewed as a source of strength and a base for creating strong social capital in the future (cf. Letki and Evans 2005, Putman 1995, Acemoglu and Jackson 2012).

\section{SOCIO-ECONOMIC COSTS AND BENEFITS OF COOPERATION}

Undoubtedly, groups of agricultural producer are established for the economic and social benefits resulting from cooperation. By joining forces, farmers gain many advantages in the competitiveness of holdings, not only in selling their products on the market, but also purchasing and processing them within the group (Boguta, 2006).

The greatest socio-economic benefits resulting from participation in an agricultural producer group are as follows:

- $\quad$ reducing the number of intermediaries

- increasing affiliate income (due to lower cost of fertiliser, pesticides, transport); higher prices for uniform, highquality products, delivered on time

- unified management

- $\quad$ pooled investments (capital, credit, equipment, storage, and refrigeration)

- reliable delivery schedule

- joint advertising

- technological experience sharing

- $\quad$ market knowledge sharing

- improved partnership resulting in stronger domination, and joint problem-solving and consulting (Promocja tworzenia... 2011).

According to Czapiewska (2013), benefits from participation in an agricultural producer group are felt by both an individual producer and a larger group of producers. Individual producers participating in a group have the conditions to: adapt their production to the requirements of buyers and consumers; save time on securing supply and sale; make use of their full production capacity, as well as of the skills and experience of affiliated farmers. On the other hand, a group of producers has the ability to: operate on wholesale and commodity markets; provide supply for supermarket chains; build a steady distribution network; provide appropriate packing and packaging; stabilise sales; enter into lucrative long-term contracts with buyers. A group of agricultural producers may also hire a marketing specialist and can negotiate higher product prices or better transaction conditions than a single producer is able to.

A survey among agricultural producer groups conducted by Marosz (2013) clearly indicates that agricultural holdings affiliated with groups of producers and associated with associations increase competitiveness in the domestic market and stimulate production and development in individual farms. Additionally, Polish products are gaining popularity abroad due to regular participation by leading producers, associations, and organisations in various exhibitions in Europe and worldwide. Large quantities of uniform, quality agricultural products and food can be offered at a low retail price, which lets Polish goods maintain competitiveness against Western European products.

Another substantial economic benefit for groups of producers is the availability of financial aid. Between 2007 and 2013, under the Rural Development Programme 2007-2013, agricultural producer groups could apply for aid under the "Agricultural Producer Groups" measure. In accordance with Council Regulation (EC) No. $1698 / 2005$ of 20 September 2005 on support for rural development by the European Agricultural Fund for Rural Development (EAFRD) (OJ L 277/1 of 21 October 2005, as amended), aid was awarded to facilitate the establishment and administrative operation of producer groups. Flat-rate aid has been extended to groups of agricultural producers in the first five years of their operation. The crop sector, livestock sector, and special branches of agricultural production were supported. From programme launch under the Rural Development Programme 2007-2013 ${ }^{1}$ until 31 October 2015, PLN 782.7 million was paid, according to the data of the Agency for Restructuring and Modernisation of Agriculture. These resources aided groups of agricultural producers in administrative operations and enabled the purchase of equipment, capital goods, and investment in buildings and facilities.

According to Regulation (EU) No. 1305/2013 of the European Parliament and of the Council, the European Commission favoured further support for establishment and operation of producer groups and organisations. In Poland, the measure "Setting-up of producer groups and organisations" has been included in the Rural Development Programme for 2014-2020. The measure is aimed at adapting the production to market requirements, jointly placing goods on the 
market (including preparation for sale), centralising sales and supply to wholesalers and establishing common rules on production information, with particular regard to harvesting and availability. Furthermore, the measure is intended to foster other activities that may be carried out by producer groups, such as the development of business and marketing skills or organisation and facilitation of innovation processes. Beneficiaries of the programme may include agricultural producer groups and producer organisations established after 1 January 2014, operating as entrepreneurs made up of physical persons and fulfilling additional eligibility criteria. The third edition of the Rural Development Programme offers support of $10 \%$ in the first year, $8 \%$ - in the second, $6 \%$ - in the third, 5\% - in the fourth, and $4 \%$-in the fifth. A maximum of EUR 100,000 equivalent is set for each of the five years [PROW... 2014-2020].

In spite of the multiplicity of benefits to be gained from cooperation, the level of economic organisation among farmers in Poland is still low. According to Boguta (2014), only 15\% of the approximately 250,000 larger commercial agricultural producers, who are natural candidates for group founders, belong to any group. Producers who attempt to organise often encounter problems. Farmers still lack experience with operating under market conditions and have difficulty in assessing the economic situation. Low education about group activities of agricultural producers is an important factor. Inadequate knowledge of laws, registration procedures and insufficient experience with business activity pose additional difficulties in establishing such organisations. Another problem is low trust among farmers and their unwillingness to integrate. "Unhealthy competition" may also arise among group members and could be exacerbated by large discrepancies in members' production capacity. Unwillingness to collaborate may also be due to the farmers' apprehension of losing their freedom to make decisions and having to submit to group regulations. Some farmers decide to operate independently to keep their autonomy, even at the price of lower productivity and competitiveness (Knoblauch and Kisiel, 2005). Table 3 shows an overview of barriers to farmers' collaboration.

Table 3 Barriers to farmers' collaboration in producer groups

\begin{tabular}{|c|c|}
\hline Internal Barriers & External Barriers \\
\hline $\begin{array}{l}\text { - lack of a leader among producers; } \\
\text { - } \quad \text { bad experiences of farmers; } \\
\text { - } \quad \text { passivity; } \\
\text { - } \text { disorientation in new economic conditions; } \\
\text { - } \quad \text { reluctance towards organisational innovation; } \\
\text { - } \quad \text { lack of losing autonomy; } \\
\text { - lack of mutual trust; } \\
\text { - } \quad \text { unhealthy competition" among group members; } \\
\text { - } \text { fragmentation and discrepancies in production capacities } \\
\text { - } \quad \text { expectation of quick profits; } \\
\text { - lack of financial resources for the necessary duties; } \\
\text { - treating membership fees as yet another drain on finances. }\end{array}$ & $\begin{array}{l}\text { - lack of good models; } \\
\text { - limited access to information and practical knowledge on } \\
\text { - } \quad \text { laws inadequate to farmers' capabilities; } \\
\text { - } \quad \text { inadequate public financing; } \\
\text { - lack of subsidised loans for forming producer groups; } \\
\text { - } \quad \text { obligatory bookkeeping by business entities; } \\
\text { - } \quad \text { difficulties in dealing with state offices and institutions, } \\
\text { i.a. Tax Office, Social Insurance Institution (ZUS). }\end{array}$ \\
\hline
\end{tabular}

Empirical research conducted by Knecht (2012) among agricultural producer group members in Poland shows that inadequate financial resources for membership fees are a significant barrier to group formation. Farmers consider membership fees a constant drain on their finances. Respondents also pointed to insufficient public funding as a serious barrier. In their opinion, EU subsidies are a weak incentive to establish producer groups. However, considering the large number and amount of subsidies for rural development, including the creation of groups of agricultural producers in Poland, this opinion may be a result of farmers' lack of information rather than the factual circumstances.

\section{CONCLUSIONS}

The problem of association among agricultural producers in Poland is broadly discussed in the literature on the subject. Deliberations on sources of economically effective cooperation between farmers touch upon primarily such social aspects as: developing relations between farmers; pursuing a common goal which impacts the division of tasks in a group and the reduction of individual independency; members' trust issues; production task complexity which may drive interest in cooperation, although it may also result in competition or even conflict.

Research suggests that the reasons for forming groups of producers in Poland include various economic benefits related to production on a higher scale and to achievement synergies through acting together. These include, among others, preparation and sale of products of higher quality from a more diverse range. Such benefits are also of social nature and are connected with farmers learning how to act together as well as with increasing trust among organisation members in order to cooperate and implement certain projects. One must not forget that cooperation is not only about advantages there are some obstacles. Risks arising from the establishment and operation of groups of producers in Poland include, among other things, the lack of a well-established tradition of cooperation due to specific historical events, unwillingness to cooperate because of lack of trust between farmers and expectations of quick financial gains. 
Presently, in Poland there are slightly more than 1,500 groups of agricultural producers and those which operate in the fruit and vegetable sector. However, the number of producers working together in that sector is far from satisfactory when compared to other Member States of the EU. EU funds provide an opportunity to increase the number of groups of producers.

The support provided to groups of agricultural producers to date under the Rural Development Programme for 2007-2013 will be continued in 2014-2020 on better terms for the interested parties. It is extremely important in that process for farmers to be able to count on assistance of agricultural advisory centres. Encouraging groups to expand and form more capable entities should become a new priority of authorities responsible for agricultural policy of Poland. It is capable and strong groups of producers that will largely determine competitiveness of that sector in the long run.

\section{REFERENCES}

1. Acemoglu, D., Jackson, M. 2012. History, Expectations and Leadership in the Evolution of Social Norms. NBER Working Paper No. 17066, Cambridge.

2. Adamik, A. 2007. Collaboration, cooperation and alliance as a business developmental stage - systematics of the problem. In: Organisation development management, ed.: S. Lachiewicz, Łódź.

3. Agency for Restructuring and Modernisation of Agriculture. 2014. Support programme for fresh fruit and vegetable production. [Access mode]:

4. Agency for Restructuring and Modernisation of Agriculture. 2014. Producer groups and organisations' interest in financial support within a common organisation in the fruit and vegetable market. Available at www.arimr.gov.pl/pomoc-unijna/inne-formypomocy/pomoc-na-rynku-owocow-iwarzyw/zainteresowanie-grup-i-organizacji-producentow-pomoca-finansowa-w-ramachwspolnej-organizacji-rynku-owocow-i-warzyw.pl [Accessed on April/2015].

5. Będzik, B. 2008. Social capital as an important factor in rural area development. Studies and Articles of the Faculty of Economic Sciences, University of Szczecin, No. 8, pp. 39-53.

6. Boguta, W. 2006. Organisation and operation of agricultural producers' groups. The National Co-operative Council, Warsaw.

7. Boguta, W. 2014. Rural co-operatives as one of the main forms of common economic activity of individuals. The National Cooperative Council, Warsaw.

8. Cameron, R., Neal, L. 2004. The Economic History of the World: From Palaeolithic to Modern Times. Ed.: Książka i Wiedza (Books and Economics), Warsaw.

9. Chlebicka, A. 2011. Factors of a successful agricultural producers' group. Journal of Agribusiness and Rural Development, No. 4(22), pp. 59-73.

10. Chlebicka, A. 2013. Development assessment and perspectives of support to Polish producers' groups. Studia Ekonomiczne $i$ Regionalne (Economic and Regional Studies), Vol. VI, No. 4, pp. 31-42. [In Polish]

11. Chlebicka, A., Fałkowski, J., Łopaciuk-Gonczaryk, B. 2014. Agricultural producers' groups and social capital - potential correlations. Wieś i rolnictwo (Rural areas and agriculture), No. 3 (164), pp. 137-156. [In Polish]

12. Chlebicka, A., Fałkowski, J., Wołek, T. 2008. Formation of agricultural producers' groups and price variability. Publishing Board of the Foundation for Support Programmes for Agriculture, FAPA, Warsaw.

13. Chloupkova, J., Svendsen, G.H.L., Svendsen, G.T. 2003. Building and Destroying Social Capital: The Case of Cooperative movements in Denmark and Poland. Agriculture and Human Values, No. 20, pp. 355-369.

14. Corning, P.A. 1998. The Synergism Hypothesis on the Concept of Synergy and It's Role in the Evolution of Complex Systems. Journal of Social and Evolutionary Systems, No. 21(2), pp. 30.

15. Czapiewska, G. 2013. Role of agricultural producers' groups in the development of rural areas in Pomerania. Acta Universitatis Lodziensis, Folia Geographica Socio-Oeconomica, No. 13, pp. 165-178.

16. Social diagnosis 2015. Conditions and quality of Poles: report. Ed.: J. Czapiński, T. Panek. Role of Social Monitoring, Warsaw.

17. Fedyszak-Radziejowska, B. 2006. Rural social capital. People - local community, education, ed. K. Szafraniec. IRWiR PAN, Warsaw, pp. 71-120.

18. Fulton, M. 1999. Development assessment and perspectives of support to Polish producers' groups. Studia Ekonomiczne $i$ Regionalne (Economic and Regional Studies), Vol. VI, Iss. 4, 31-42. [In Polish]

19. Glabiszewski, W., Sudolska, A. 2009. Role of cooperation in the process of developing business competitive advantage. Organisation and Management, No. 2(136), pp. 9-23.

20. Halamska, M. 2011. Social condition of rural Polish. Structure, capital and civic community in the 1st decade of the 21 st century. In: Rural development in Poland. Policy diagnoses, strategies, concepts, ed.: I. Nurzyńska, M. Drygas, IRWiR PAN, Warsaw, pp. 39-55.

21. Kłodziński, M. 2006. Social and economic activation of rural communes and small towns. IRWiR PAN, Warszawa.

22. Knecht, D. 2012. Agricultural producers' groups with particular analysis of pigs. Status and development perspective. Ed.: Wrocław University of Environmental and Life Sciences. Wrocław.

23. Knoblauch, L., Kisiel, R. 2005. Integration processes based on the example of producers' groups from north-eastern Poland. The Wojciech Kętrzyński Scientific Research Centre, Olsztyn

24. Kostro, K. 2005. Social capital in economic theory - approach review. In: Social capital. Social economics. Ed.: T. Kaźmierczak, M. Rymsza. Institute of Public Affairs, Warsaw.

25. Kożuch, B. 2007. Organisation Science. Ed.: CeDeWu Wydawnictwa Fachowe, Warsaw.

26. The National Network of Rural Areas. 2015. Agricultural Producers' Groups. Available at http://ksow.pl/grupy-producentowrolnych.html (Accessed on 21/06/2015).

27. Krzyżanowska, K. 2013. Farmers' organisation in agricultural producers' groups. Economic and agricultural sciences in the context of economic changing demand, SGGW, Warszawa, pp. 63-74.

28. Krzyżanowska, K. 2003. Farmers' common undertakings and conditions. Ed.: SGGW, Warszawa.

29. Lemanowicz, M. 2004. Successful farmers active in agricultural producers' groups. Scientific yearbooks SERiA, Vol. VI, Iss.1, pp. 127-132.

30. Letki, N., Evans, G. 2005. Endogenizing Social Trust: Democratization in East-Central Europe. British Journal of Political Science, No 35(3), pp. 515-529. https://doi.org/10.1017/S000712340500027X 
31. Marosz, A. 2013. Analysis of factors of dynamics of formation and development of producers' groups. Analysis conducted within a task financed by the Ministry of Agriculture and Rural Development. Institute of Horticulture, Department of Seed Production and Nursing of Decorative Plants, Decorative Plants' Nursing Shop, Skierniewice.

32. Matysiak, A. 1999. Social capital sources. Ed.: Wrocław Economic Academy, Wrocław.

33. Michalewska-Pawlak, M. 2010. Opportunities and barriers of social capital development in Polish rural areas. [in:] Social capital - interpretations, impressions, operationalisation, M. Klimowicz, W. Bokajło, (red.). CeDeWu Sp. z o.o., Warsaw, pp. $185-202$.

34. Morrow, J., Hansen, M., Batista, J. 2003. Trust and Its Impact on Members of a Farmer Marketing Cooperative. Brigham Young University.

35. Murray, C. 2005. Social Capital and Cooperation in Central and Eastern Europe, A Theoretical Perspective. ICAR Discussion Paper 9, Humbold University, Berlin.

36. Pietrzyk, I. 2000. EU Regional Policy and regions in the European Member States. Ed.: Naukowe PWN, Warsaw.

37. Rural Area Development Programme for 2007-2013, Ministry of Agriculture and Rural Development, www.minrol.gov.pl [In Polish]

38. Rural Area Development Programme for 2014-2020, Ministry of Agriculture and Rural Development, www.minrol.gov.pl [In Polish]

39. Polish agricultural producers' group promotion 2011. Ministry of Agriculture and Rural Development, Warsaw. [In Polish]

40. Prus, P., Wawrzyniak, B.M. 2009. Agricultural producers' groups in the light of Rural Area Development Operational Programme for 2004-2006 and 2007-2013. In: Business development and common entrepreneurship in agriculture in the light of European Union integration, ed.: S. Zawisza. Ed.: University of Technology and Natural Sciences in Bydgoszcz, Bydgoszcz, pp. 151-154. [In Polish]

41. Putnam, R.D. 1995. Democracy in action: Civic traditions in contemporary Italy. "Znak" Social Editorial Institute. Kraków.

42. Regulation (EU) No 1305/2013 of the European Parliament and of the Council of 17 December 2013 on support for rural development by the European Agricultural Fund for Rural Development (EAFRD) and repealing Council Regulation (EC) No 1698/2005, Dz.U. L. 347 of 20.12.2013, 487.

43. Council Regulation (EC) No. 1234/2007 of 22 October 2007 establishing a common organisation of agricultural markets and on specific provisions for certain agricultural products (Single CMO Regulation). Official Journal of the European Union, L 299, of 16.11.2007, pp. 88-95, pp. 132-153.

44. Council Regulation (EEC) No 1360/78 of 21 June 1978 on support of the Community to agricultural producers' associations, 1978, Council (EC), Brussels.

45. Regulation (EU) No 1698/2005 of the European Parliament and of the Council of 20 September 2005 on support for rural development by the European Agricultural Fund for Rural Development (EAFRD). Official Journal of the European Union, L 277, of 21.10.2005, pp. 1-40.

46. Council Regulation (EEC) No 26 of 20 April 1962 on the principles of competition on the Common Market, 1962, Council (EC), Brussels.

47. Regulation of the Council (EC) No. 952/97 of 20 May 1997 on agricultural producers' groups and associations. 1997. EU Council, Brussels.

48. Sierocińska, K. 2011. Social capital. Definition, measurement and types. Economic studies, No. 1, pp. 69-86.

49. Spychalski, G. 2008. Human resource capital and social capital of the Polish rural areas. Studies and Articles of the Faculty of Economic Sciences, University of Szczecin, No. 8, pp. 397-405.

50. Szeląg-Sikora, A., Oleksy-Gębczyk, A. 2013. Producers' groups as an example of common business in agriculture. Management and Finances (Journal of Management and Finance), Vol. 11, No. 1(2), pp. 341-351. [In Polish]

51. Act of 11 September 2015 on an amendment of the Act on agricultural producers' groups and their associations and on amendment of other acts and the Act on support for rural development by the European Agricultural Fund for Rural Development (EAFRD) for 2014-2020. Dz.U.2015, item 1888.

52. Act of 15 September 2000 on agricultural producers' groups and their associations and on amendments to other acts. 2000. Dz. U. No. 88 , item 983.

53. Act of 19 December 2003 on organisation of the fruit and vegetable market, hops market, dry fodder market and the market of flax and hemp cultivated for yarn. Dz.U. 2003 No. 223 item 2221 as amended, uniform text as of 23.11.2012.

54. Wieruszewska, M. 200. Rural community - bases of self-organisation. In: Self-organisation in rural communities - forms, structures, differentiation. Ed.: M. Wieruszewska. IRWiR PAN, Warszawa, pp. 12-90.

55. Wojewódzka, A. 2006. Importance of social capital in local development. Sustainable and stable development of rural areas and agriculture. Scientific papers SGGW No. 40, Warszawa.

56. Woolcock, M. 2001. The Place of Social Capital in Understanding Social and Economic Outcomes. The Canadian Journal of Policy Research, No. 1, pp. 11-17.

57. Zielińska-Szczepkowska, J., Kisiel, R. 2016. Association of agricultural producers as an example of co-operation in the agricultural sector - experiences of some European Union member States. Global Agriculture Problems, No. 2, pp. 373-386. 